\title{
IMPROVING STUDENTS' READING COMPREHENSION THROUGH JIGSAW TECHNIQUE
}

\author{
Halimah $^{1}$, Helpiana Purba ${ }^{2}$, Cynantia Rachmijati ${ }^{3}$ \\ ${ }^{1}$ IKIP Siliwangi \\ ${ }^{2}$ IKIP Siliwangi \\ ${ }^{3}$ IKIP Siliwangi \\ ${ }^{1}$ halimahazzahra97@gmail.com, ${ }^{2}$ purba_helpiana@yahoo.com, ${ }^{3}$ cynan_tia@yahoo.com
}

\begin{abstract}
The purpose of this research is to investigate of using jigsaw technique to improve reading comprehension at the tenth grade students in SMAN 1 Ngamprah. The total number of sample in this study was 60 students in two classes. It used pre-experimental design that applies in the treatments to measure the significant scores pre-test and post-test. Pre-test was applied in the first meeting. Whereas post-test was applied after the treatments given. After given pre-test and post-test, the researcher got the mean scores in both of the class. There are 57.00 and 80.17 in experimental class and the control class are respectively 57.00 and 79.17 . The result show that using jigsaw technique had the positive effect in improving reading comprehension because there was a significant post- test scores of students in two classes with the level significance 0.05 . The significance in post-test is 0.355 it was higher than 0.05. It concluded that students' response toward the implementation of jigsaw technique is effective because they are enjoyed and interested in the learning process. Moreover, the jigsaw technique could help them to improve their reading comprehension.
\end{abstract}

Keywords: Jigsaw Technique, Reading Comprehension

\section{INTRODUCTION}

In learning English, there are four language skills that must be learned by the students. There are listening, speaking, reading and writing. These four language skills are integrated and related to each other. Among the other language skills, reading is one of the language skills that is not easy to be mastered, because it is only accept what is conveyed by the author through written text. According to Iskandar Wassid and Suhendar (2008) (Al-Darayseh, 2014) the purpose of reading is to recognize written text a language, interpret and use foreign vocabulary, understand information that is stated explicitly and implicitly, understand the meaning.

Based on curriculum 2013 (Kurtilas) (Smp \& Surakarta, 2018), all skills in teaching and learning English that are integrated each other must be learn and taught by both students and teacher, include reading skill. According to He Ji Sheng (2000) (Rakhmawati, 2016) reading is the process of recognition, interpretation, and perception of written or printed material. It involves the recognition of words, clauses, phrases and letters. It can be considered a simpler process than comprehension. Beside, comprehension is a process of negotiate the understanding between the reader and writer.

On the other hand, reading comprehension is redundant phrase, because without comprehension, reading is not truly happened. Therefore, reading comprehension is a process to get meaning of the text from the writer that involves experience and prior knowledge that 
the reader have. Considering the importance of reading comprehension, the teacher can use some methods in teaching reading that can make the students enjoy to learn English. One of the methods is by using jigsaw technique.

Jigsaw technique is helpful in motivating students to accept responsibility for learning something well enough to teach it to their peers. It also gives each students a chance to be in the spotlight. Jigsaw is one of the cooperative learning method that consists of 4-5 students with heterogeneous group. Every students is responsible to learn the problems of the material that provided and delivering the material to other group members. Furthermore, Rusman (2008) (Study, Students, \& Year, 2017) said that learning jigsaw model can also called cooperative experts, because each member is faced with a different problem. However, the problems faced by each group are the same. We called it the expert team were discuss of the problems faced. Then, the result of the discussion were brought to the original group and delivered to the group members.

In the jigsaw technique, there are groups of experts and groups of origin. The original group is the initial group of students that consists of how many members of the expert group are formed with regard to diversity and background. While the expert group, which is a group of students that consists of members of other groups (groups of origin) who are assigned to explore certain topics for later explained to members of the original group.

There are 8 steps considered to be important in the implementation of the jigsaw classroom. Huda (2013) (Smp \& Surakarta, 2018) describes them as:

1. Teacher divided lesson topics into four sections/subtopics. For example, the topic of the novel is divided into lines, characters, settings, and themes.

2. Before the subtopics are given, the teacher gives an introduction to the topic that will be discussed at the meeting that day. The teacher can write this topic on the board and ask students what they know about the topic. This brainstorming activity is intended to enable students to be better prepared to face new learning material.

3. Students are divided into groups of four.

4. The first section/subtopic are given to students/members one, while students/members receive the second part/subtopic.

5. Then, students are asked to read/work on their respective sections/subtopics.

6. After completion, students immediately discuss the section/subtopic that is read/done each with their fellow members. In this activity, students can complement and interact with one another.

7. Especially for reading activities, the teacher can read, the teacher can divide the parts of a story that has not been intact with each student. Students read these sections to predict what is told in the story.

8. This activity can end with a discussion on the topic. This discussion can be done between groups or with all students.

This method can be applied to materials related to reading, writing, listening or speaking skills. In jigsaw the teacher must understand the abilities and experiences of students and help students activate this scheme, so that the subject matter becomes more meaningful. Teachers also provide many opportunities for students to process information and improve communication skills.

The key of this technique is interdependence of each students towards team members who 
provide the information needed. It means that students must have responsibility, positive cooperation and interdependence to get information and solve the problems was given.

\section{METHOD}

This research used quantitative method and pre-experimental design to figure out whether some influence of using jigsaw as method on students reading comprehension. According to Arikunto (2006) (Rakhmawati, 2015) states this design will be done of twice in observation. There are pre-test before doing the treatment and after treatment called post-test.

The population of this study was the whole students of SMAN 1 Ngamprah on the second semester in academic year 2018/2019. There are 8 class of the tenth grade. There are two major. That is science and social. There are 240 students altogether who had been become the population of this research. The researcher took the sample is two classes, there are X Social 1 and X Social 4, from each class consists of 30 students. The researcher took X social 1 as the experimental class and $\mathrm{X}$ social 4 as the control class. The researcher is assessing student achievement in reading comprehension through jigsaw technique in experimental class. While the control class, the researcher used discovery learning. In obtaining the data, the researcher used pre-test and post-test as the instrument to get the result.

\section{RESULTS AND DISCUSSION}

\section{Results}

Here is the report of concerning the data by pre-test and post-test. The following table shows score of the test:

Table 1. Score of Students Experimental Class

\begin{tabular}{ccccc}
\hline No. & Name & Gender & Pre-test & Post-test \\
\hline 1 & Student 1 & F & 40 & 70 \\
2 & Student 2 & F & 50 & 75 \\
3 & Student 3 & M & 40 & 80 \\
4 & Student 4 & F & 45 & 75 \\
5 & Student 5 & F & 60 & 70 \\
6 & Student 6 & F & 55 & 80 \\
7 & Student 7 & M & 65 & 90 \\
8 & Student 8 & F & 50 & 70 \\
9 & Student 9 & F & 40 & 85 \\
10 & Student 10 & M & 70 & 90 \\
11 & Student 11 & F & 65 & 75
\end{tabular}




\begin{tabular}{|c|c|c|c|c|}
\hline 12 & Student 12 & $\mathrm{~F}$ & 60 & 80 \\
\hline 13 & Student 13 & $\mathrm{M}$ & 50 & 85 \\
\hline 14 & Student 14 & $\mathrm{~F}$ & 70 & 75 \\
\hline 15 & Student 15 & $\mathrm{~F}$ & 55 & 90 \\
\hline 16 & Student 16 & $\mathrm{M}$ & 40 & 80 \\
\hline 17 & Student 17 & $\mathrm{M}$ & 50 & 85 \\
\hline 18 & Student 18 & $\mathrm{~F}$ & 75 & 80 \\
\hline 19 & Student 19 & $\mathrm{M}$ & 45 & 95 \\
\hline 20 & Student 20 & M & 50 & 70 \\
\hline 21 & Student 21 & $\mathrm{M}$ & 70 & 80 \\
\hline 22 & Student 22 & $\mathrm{~F}$ & 55 & 80 \\
\hline 23 & Student 23 & $\mathrm{~F}$ & 60 & 90 \\
\hline 24 & Student 24 & M & 75 & 70 \\
\hline 25 & Student 25 & $\mathrm{~F}$ & 45 & 85 \\
\hline 26 & Student 26 & $\mathrm{M}$ & 60 & 70 \\
\hline 27 & Student 27 & $\mathrm{M}$ & 75 & 75 \\
\hline 28 & Student 28 & $\mathrm{~F}$ & 60 & 85 \\
\hline 29 & Student 29 & M & 60 & 75 \\
\hline \multirow[t]{2}{*}{30} & Student 30 & $\mathrm{M}$ & 75 & 95 \\
\hline & Mean & & 57.00 & 80.17 \\
\hline
\end{tabular}

Table 2. Score of Students Control Class

\begin{tabular}{ccccc}
\hline No. & Name & Gender & Pre-test & Post-test \\
\hline 1 & Student 1 & F & 55 & 75 \\
2 & Student 2 & F & 45 & 80 \\
3 & Student 3 & M & 60 & 85 \\
4 & Student 4 & F & 65 & 70
\end{tabular}




\begin{tabular}{|c|c|c|c|}
\hline 5 & Student 5 & $\mathrm{~F}$ & 70 \\
\hline 6 & Student 6 & M & 45 \\
\hline 7 & Student 7 & $\mathrm{~F}$ & 50 \\
\hline 8 & Student 8 & $\mathrm{~F}$ & 70 \\
\hline 9 & Student 9 & $\mathrm{~F}$ & 65 \\
\hline 10 & Student 10 & M & 50 \\
\hline 11 & Student 11 & M & 60 \\
\hline 12 & Student 12 & $\mathrm{~F}$ & 45 \\
\hline 13 & Student 13 & $\mathrm{~F}$ & 40 \\
\hline 14 & Student 14 & M & 40 \\
\hline 15 & Student 15 & M & 60 \\
\hline 16 & Student 16 & $\mathrm{~F}$ & 50 \\
\hline 17 & Student 17 & $\mathrm{~F}$ & 50 \\
\hline 18 & Student 18 & $\mathrm{M}$ & 65 \\
\hline 19 & Student 19 & M & 40 \\
\hline 20 & Student 20 & M & 40 \\
\hline 21 & Student 21 & $\mathrm{~F}$ & 55 \\
\hline 22 & Student 22 & $\mathrm{~F}$ & 50 \\
\hline 23 & Student 23 & $\mathrm{~F}$ & 60 \\
\hline 24 & Student 24 & $\mathrm{~F}$ & 70 \\
\hline 25 & Student 25 & $\mathrm{~F}$ & 65 \\
\hline 26 & Student 26 & M & 70 \\
\hline 27 & Student 27 & $\mathrm{~F}$ & 60 \\
\hline 28 & Student 28 & $\mathrm{~F}$ & 40 \\
\hline 29 & Student 29 & $\mathrm{~F}$ & 55 \\
\hline
\end{tabular}




\begin{tabular}{ccccc}
30 & Student 30 & F & 60 & 90 \\
\hline Mean & & 57.00 & 79.17 \\
\hline
\end{tabular}

Table 3. Descriptive Statistics Experimental Class

\begin{tabular}{cccc}
\hline & N & Minimum & Maximum \\
\hline Pre-test & 30 & 40 & 75 \\
Post-test & 30 & 70 & 95 \\
\hline
\end{tabular}

Table 4. Descriptive Statistics Control Class

\begin{tabular}{cccc}
\hline & N & Minimum & Maximum \\
\hline Pre-test & 30 & 40 & 70 \\
Post-test & 30 & 70 & 90 \\
\hline
\end{tabular}

Based on SPSS 19 program, it found score maximum and minimum of pre- test (the analysis before treatment). In experimental class, the score of minimum pre-test was 40.00 and score of maximum was 75.00. The score of minimum post-test was 70.00 and the score maximum was 95.00. In control class, the score of minimum pre-test was 40.00 and score of maximum was 70.00. Then, score of minimum post-test was 70.00 and the score maximum was 90.00 . It was tell us that score maximum and minimum of post-test is higher than pre-test. In other words, it is assumed that jigsaw technique is effective to improve students' reading comprehension.

The normal distribution test was used to check whether the tests were normally or not. The analysis used Kolmogorov-Smirnov formula through SPSS 19 for windows. It used significant criteria 0.05 . The data was stated in normal distribution if significant point bigger than $5 \%$ or 0.05 (i.e. $a>0.05$ ). The following table was the result of normally distribution on pretest.

Table 5. Test of Normality Distribution

\begin{tabular}{|rl|r|r|r|r|r|r|}
\hline & & \multicolumn{3}{|c|}{ Kolmogorov-Smirnov } & \multicolumn{3}{c|}{ Shapiro-Wilk } \\
\cline { 2 - 7 } & Kelas & Statistic & \multicolumn{1}{c|}{ Df } & \multicolumn{1}{c|}{ Sig. } & \multicolumn{1}{c|}{ Statistic } & \multicolumn{1}{c|}{ Df } & Sig. \\
\hline \multirow{2}{*}{ Pretest } & Experimental & .129 & 30 & $.200^{*}$ & .931 & 30 & .052 \\
& Control & .145 & 30 & .110 & .939 & 30 & .083 \\
\hline
\end{tabular}

Based on table 5, it shows the significance in experimental class is 0.200 and the significance in control class is 0.110 . Because significant is higher than 0.05 it can be concluded that the test has normal distribution.

Conducted normal distribution test, based on SPSS 19 program was employed to analyze the data and to find out the homogeneity of variance. To find the samples variance were homogenous, the significant of the data must be higher than 0.05 . The output as shown the following table: 
Table 6. Test of Homogeneity Variances

\begin{tabular}{|ll|r|r|r|r|}
\hline & Levene Statistic & df1 & df2 & \multicolumn{1}{c|}{ Sig. } \\
\hline Pretest & Based on Mean & .317 & 1 & 58 & .575 \\
& Based on Median & .323 & 1 & 58 & .572 \\
& Based on Median and with & .323 & 1 & 57.343 & .572 \\
adjusted df & & & & \\
& Based on trimmed mean & .325 & 1 & 58 & .571 \\
\hline
\end{tabular}

From the table 6 the significance value was 0.575 , it is higher than the significance 0.05 (i.e. $0.575>0.05$ ). So, it was conclude that the variances data is homogenous.

After the researcher got the result of the data is normal and homogenous, the researcher find out the sample T-test. The table as follows:

Table 7. Independent Samples Test

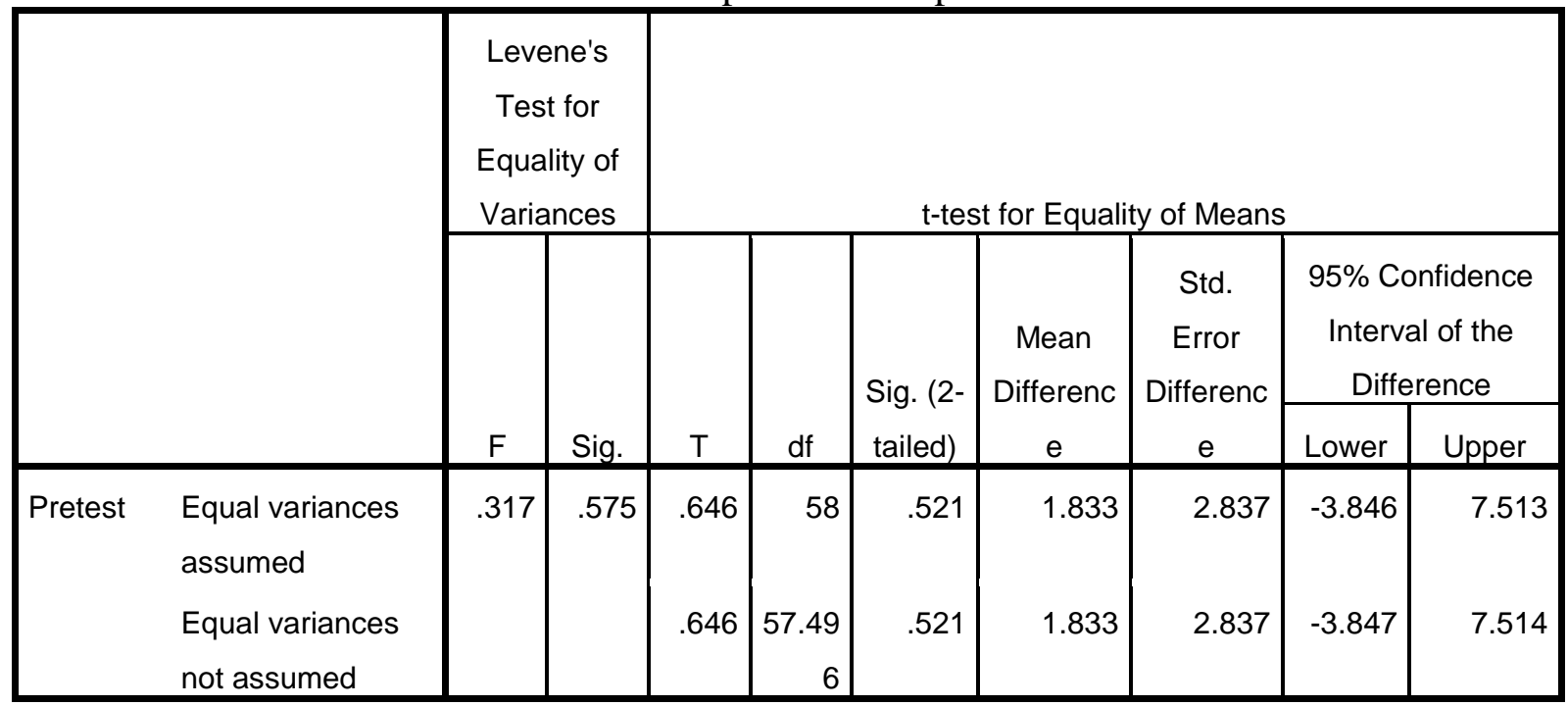

After computing the pre-test scores obtained by the experimental and control class, the sig (2 tailed) was 0.521. Because significance is higher than 0.05 , so it can be conclude that $\mathrm{H}_{0}$ is accepted. It means the ability of experimental and control class are the same.

The analysis of post-test data is performed by doing similar steps as the pre-test data.

Table 8. Tests of Normality Distribution

\begin{tabular}{|rl|r|r|r|r|r|r|}
\hline & \multicolumn{4}{|c|}{ Kolmogorov-Smirnov } & \multicolumn{3}{c|}{ Shapiro-Wilk } \\
\cline { 2 - 8 } & Kelas & \multicolumn{1}{c|}{ Statistic } & \multicolumn{1}{c|}{ Df } & \multicolumn{1}{c|}{ Sig. } & \multicolumn{1}{c|}{ Statistic } & \multicolumn{1}{c|}{ df } & Sig. \\
\hline \multirow{2}{*}{ Posttest } & Experimental & .149 & 30 & .086 & .901 & 30 & .009 \\
& Control & .153 & 30 & .071 & .898 & 30 & .008 \\
\hline
\end{tabular}

From the data analyze above, the significance value obtained for the post-test of the experimental class was 0.086 and the control class was 0.071 . Because the significance in 
experimental and control class was higher than the significance level of 0.05 . The result shown that the data had a normal distribution.

Table 9. Test of Homogeneity of Variance

\begin{tabular}{|ll|r|r|r|r|}
\hline & Levene Statistic & df1 & df2 & \multicolumn{1}{c|}{ Sig. } \\
\hline Posttest & Based on Mean & .005 & 1 & 58 & .944 \\
& Based on Median & .000 & 1 & 58 & 1.000 \\
Based on Median and with & .000 & 1 & 58.000 & 1.000 \\
adjusted df & & & & \\
Based on trimmed mean & .006 & 1 & 58 & .937 \\
\hline
\end{tabular}

Based on table 9 the significance was 0.944 , it means the data is homogenous because significance 0.944 is higher than 0.05 .

Table 10. Independent Samples Test

\begin{tabular}{|c|c|c|c|c|c|c|c|c|c|c|}
\hline & \multicolumn{2}{|c|}{$\begin{array}{l}\text { Levene's } \\
\text { Test for } \\
\text { Equality of } \\
\text { Variances }\end{array}$} & \multicolumn{7}{|c|}{ t-test for Equality of Means } \\
\hline & & \multirow[b]{2}{*}{$\mathrm{F}$} & \multirow[b]{2}{*}{ Sig. } & \multirow[b]{2}{*}{$t$} & \multirow[b]{2}{*}{ df } & \multirow{2}{*}{$\begin{array}{l}\text { Sig. } \\
(2- \\
\text { tailed) }\end{array}$} & \multirow{2}{*}{$\begin{array}{c}\text { Mean } \\
\text { Difference }\end{array}$} & \multirow{2}{*}{$\begin{array}{l}\text { Std. Error } \\
\text { Difference }\end{array}$} & \multicolumn{2}{|c|}{$\begin{array}{c}95 \% \\
\text { Confidence } \\
\text { Interval of the } \\
\text { Difference }\end{array}$} \\
\hline & & & & & & & & & Lower & Upper \\
\hline Posttest & $\begin{array}{l}\text { Equal variances } \\
\text { assumed }\end{array}$ & .005 & .944 & .374 & 58 & .710 & .667 & 1.783 & -2.903 & 4.236 \\
\hline & $\begin{array}{l}\text { Equal variances } \\
\text { not assumed }\end{array}$ & & & .374 & 57.995 & .710 & .667 & 1.783 & -2.903 & 4.236 \\
\hline
\end{tabular}

From the computation of post-test scores of the experimental and control class, it shows that after being given some treatments, there are differences between the scores of pre-test and post-test in experimental and control class. After the significance in post-test was divided, the result was 0.355 , Because significance is higher than 0.05 , it concluded that $\mathrm{H}_{0}$ is accepted. It means the achievement of experimental and control class are the same.

\section{Discussion}

This research involved experimental and control class with implementation of pre-test, treatments and post-test in four meetings. In the first meeting, the pre-test was given to the experimental and control class. Then, the researcher given treatments twice using jigsaw technique in experimental class and without jigsaw technique in control class. In the last meeting, the post-test was given to the both of the class.

After collecting the data, the researcher got the result of students score in experimental and control class. From the result, the researcher found the increase of the pre-test and post-test 
scores in the both of class. While the data shows that the both of the class have the ability and achievement are the same.

\section{CONCLUSION}

From the result of this research, it can be concluded that the implementation of jigsaw technique in experimental class is effective in improving students' reading comprehension. The jigsaw technique gives positive effect and make the students enthusiastic in learning process.

\section{ACKNOWLEDGMENTS}

This journal have not been completed without support, guidance from individual and institution. Therefore, the researcher would likes to express special thanks to:

1. Cynantia Rachmijati, M.M.Pd. and Aseptiana Parmawati, M.Pd. as the advisor for their guidance and help to finish this journal.

2. Syaepuddin, S.Pd. as the headmaster, and Dety Fakussilianti, S.Pd. as the English teacher in SMAN 1 Ngamprah for giving the contribution the researcher was conducting the research at the school.

3. All the students of the second semester of tenth grade in SMAN 1 Ngamprah for giving nice participation and great attention during the research.

4. Other researcher for references in teaching reading comprehension using jigsaw technique.

5. My beloved friends to giving support, advice, and suggestion.

\section{REFERENCES}

Al-Darayseh, A.-M. A. (2014). The Impact of Using Explicit/Implicit Vocabulary Teaching Strategies on Improving Students' Vocabulary and Reading Comprehension. Theory and Practice in Language Studies, 4(6), 1109-1118. https://doi.org/10.4304/tpls.4.6.11091118

Rakhmawati, D. (2015). the Effectiveness of Know-Want To Know-Learned ( Kwl ) Strategy in Reading Comprehension, 1(1), 25-31. https://doi.org/10.1016/j.anbehav.2008.08.006

Rakhmawati, D. (2016). the Influence of Vocabulary Journal in Teaching Students' Vocabulary Mastery. Jurnal Smart, 2(1), 52-59. https://doi.org/10.26638/148.203X

Smp, A. T., \& Surakarta, M. (2018). No Title.

Study, A. E., Students, E. G., \& Year, A. (2017). The Effect of Using Jigsaw Technique to Improve Students ${ }^{\text {ee }}$ Reading Skill:, 05. 